\title{
Growth Performance and Nutritional Analysis of Spirulina platensis in Different Concentrations of Papaya Skin Powder Media
}

\author{
M. A. Toyub *a, M. Z. Uddin ${ }^{\mathrm{a}}$, M. I. Miah ${ }^{\mathrm{b}}$ and M. A. B. Habib \\ ${ }^{a}$ Department of Fisheries, Ministry of Fisheries and Livestock, Bangladesh and ${ }^{b}$ Faculty of Fisheries, \\ Bangladesh Agricultural University, Mymensingh, Bangladesh
}

\begin{abstract}
The growth performance of Spirulina platensis was studied in four different concentrations viz. 0.3, 0.4, 0.5 and 0.6 g/l of papaya (Carica papaya) skin powder media (PSPM) and in control, Kosaric Medium (KM) in triplicate. The initial cell weight of S. platensis was 6.0 mg/l which attained a maximum weight of $913.13 \mathrm{mg} / \mathrm{l}$ on the 10th day of culture in the control KM followed by $699.07,612.13,538.99$ and $377.48 \mathrm{mg} / \mathrm{l}$ that grown in $0.40,0.30,0.50$ and $0.60 \mathrm{~g} / \mathrm{l}$ of PSPM respectively. Similar trend was observed in the case of chlorophyll a content ranging 3.57 to $8.15 \mathrm{mg} / \mathrm{l}$. The specific growth rate (SGR, $\mu$ /day) of $S$. platensis on the basis of cell weight and chlorophyll a content was recorded in the ranges of 0.41 to 0.50 and 0.41 to 0.49 , respectively, for all the treatments. The SGR on the basis of cell weight and chlorophyll a was recorded significantly $(\mathrm{p}<0.05)$ higher in $\mathrm{KM}$ among all the treatments. On the other hand among the four different concentrations of PSPM, $0.40 \mathrm{~g} / \mathrm{l}$ showed significantly $(\mathrm{p}<0.05)$ higher SGR than others. The $\mathrm{pH}$ and other physico-chemical factors were within suitable range of algae culture. The cultured microalga was nutritionally rich.
\end{abstract}

Keywords: Spirulina, Papaya skin, Cell weight, Chlorophyll a

\section{Introduction}

The earliest attempts to culture algae started about more than a century ago with solutions of a few inorganic salts, actually devised for studies of vascular plants. A common feature of these media was their high contents of nutrients, particularly nitrogen, phosphorus and potassium (Rodhe, 1978). Kosaric medium (KM) is the most commonly used medium for Spirulina culture. However, it is expensive and not readily available in Bangladesh. Thus, for mass production of Spirulina, particularly in developing countries there is a need to find an effective, cheaper and readily available alternative media. Nutrients such as phosphorus and nitrogen present in agro-industrial effluents as well as in domestic wastewater may cause serious eutrophication in any water body. But these nutrients can be used to increase plant growth, such as phytoplankton, which can be utilized as natural fish food or for pharmaceutical purpose. Spirulina is one of the most promising microalgae for culture due to its high nutritional values. Spirulina platensis was successfully grown in digested sago starch factory waste water in Malaysia (Miah et al., 2000). Suitable organic media may also be used for the culture of $S$. platensis. It may be cultured in other nutrient rich media collected from vegetables.

\footnotetext{
* Corresponding author: E-mail: : toyubma@yahoo.com
}

Bangladesh is an agro-based country. Here huge amounts of vegetables such as papaya, cabage, potato, tomato etc. are producing every year. Chlorella elepsoidea was successfully cultured in papaya skin powder media by Toyub et al. (2006). So, it may be possible to culture S. platensis using papaya skin powder (PSP) as inexpensive medium. The present experiment was conducted to study the growth performance of $S$. platensis in various concentrations of PSP and to analyze its nutritional value.

\section{Materials and Methods}

\section{Collection and preparation of culture media}

For collection of papaya skin, papaya was collected from local market and sun dried primarily and then in an oven at $40^{\circ} \mathrm{C}$ for overnight. The dried skin was powdered and sieved with mesh size of $0.01 \mathrm{~mm}$ for getting fine particle. For preparation of different concentrations of papaya skin powder medium (PSPM) 0.3, 0.4, 0.5 and $0.6 \mathrm{~g}$ of papaya skin powder was added per liter of distilled water and was then thoroughly mixed. Urea $(0.2 \mathrm{~g} / \mathrm{l})$ was added to increase nitrogen content and $\mathrm{NaHCO}_{3}(6.0 \mathrm{~g} / \mathrm{l})$ was added to increase $\mathrm{pH}$ 
of each concentration of the culture media since the initial $\mathrm{pH}$ were $7.6-7.8$. Then the media were mixed well and sterilized at $120^{\circ} \mathrm{C}$ for a period of 15 minutes with moist heat by autoclave and cooled for a period of 24 hours.

\section{Preparation of control medium}

Kosaric medium (KM) was used as control medium. Composition of KM modified form of Zarouk (1966) and Phang and Chu (1999) is shown in Table I. The prepared control medium was sterilized at $120^{\circ} \mathrm{C}$ for a period of 15 minutes with moist heat by autoclave and cooled for a period of 24 hours.

Table I: Different composition of Kosaric medium (KM), modified form of Zarouk (1996); and Phang and Chu (1999) for culture of Spirulina platensis.

\begin{tabular}{c|l|c}
\hline Sl. No. & Chemicals & Amount \\
\hline 1. & $\mathrm{NaHCO}_{3}$ & $9.00 \mathrm{~g} / \mathrm{l}$ \\
2. & $\mathrm{~K}_{2} \mathrm{HPO}_{4}$ & $0.25 "$ \\
3. & $\mathrm{NaNO}_{3}$ & $1.25 "$ \\
4. & $\mathrm{~K}_{2} \mathrm{SPO}_{4}$ & $0.50 "$ \\
5. & $\mathrm{NaCl}^{\prime}$ & $0.50 "$ \\
6. & $\mathrm{MgSO}_{4}$ & $0.10 "$ \\
7. & $\mathrm{CaCl}_{2}$ & $0.02 "$ \\
8. & $\mathrm{FeSO}_{4}, 2 \mathrm{H}_{2} \mathrm{O}$ & $0.005 "$ \\
9. & $\mathrm{As} \mathrm{micronutrient} \mathrm{solution}^{\mathrm{a}}$ & $0.50 \mathrm{ml} / 1$ \\
& a) $\mathrm{As} \mathrm{micronutrient} \mathrm{solution}^{\prime}$ & $2.86 \mathrm{~g} / 1$ \\
& $\mathrm{H}_{3} \mathrm{BO}_{3}$ & $1.81 "$ \\
& $\mathrm{MnCl}_{2}, 4 \mathrm{H}_{2} \mathrm{O}$ & $0.22 "$ \\
& $\mathrm{ZnSO}_{4}, 7 \mathrm{H}_{2} \mathrm{O}$ & $0.08 "$ \\
& $\mathrm{CuSO}_{4}, 5 \mathrm{H}_{2} \mathrm{O}$ & $0.01 "$ \\
& $\mathrm{MoO}_{3}$ & $0.01 "$ \\
\hline
\end{tabular}

\section{Culture of $S$. platensis}

Stock culture of Spirulina platensis (Initially collected from Malaysia) maintained in the Department of Aquaculture, Bangladesh Agricultural University (BAU), Mymensingh, Bangladesh was used for this study. The cells were separated with the help of micro-capillary using compound microscope. Spirulina platensis was inoculated initially in prepared KM to have a pure stock culture. Five treatments, four from different concentrations $(0.3,0.4,0.5$ and $0.6 \mathrm{~g} / \mathrm{l})$ of papaya skin powder medium (PSPM) and one from KM (control) were used to grow $S$. platensis. One liter volumetric flasks were used to grow the microalga with three replications of each treatment. The microalga was inoculated into each culture flask from the stock having OD 4.8 at $620 \mathrm{~nm}$ to get $10 \%$ suspension of $S$. platensis (optical density at 620 $\mathrm{nm}=0.20$ ). All the flasks were kept under fluorescent lights (light: dark = $12 \mathrm{~h}: 12 \mathrm{~h}$ ) in the Live Food Culture Laboratory of BAU (Habib, 1998). The culture flasks were continuously aerated using electric aerator. Samplings were carried out at every alternate day from each flask to observe cell weight, chlorophyll a, optical density and physicochemical properties of culture media viz., temperature $\left({ }^{\circ} \mathrm{C}\right)$, light intensity, dissolved oxygen (DO), $\mathrm{pH}$, phosphate-phosphorus $\left(\mathrm{PO}_{4}-\mathrm{P}\right)$, nitrate-nitrogen $\left(\mathrm{NO}_{3}-\mathrm{N}\right)$, nitrite-nitrogen $\left(\mathrm{NO}_{2}-\mathrm{N}\right)$ and ammonia-nitrogen $\left(\mathrm{NH}_{3}-\mathrm{N}\right)$. All the glasswares used in the experiment were sterilized with dry heat in an oven at $70^{\circ} \mathrm{C}$ for $12 \mathrm{hrs}$. After successful completion of laboratory culture, mass culture was performed for a period of 10 days. At the 10th day of mass culture, the microalga was harvested and centrifuged at $3000 \mathrm{rpm}$ for 15 minutes to separate the microalga. The separated microalga was dried and used for proximate composition analysis.

\section{Estimation of physico-chemical properties of culture media}

Dissolved oxygen (DO) and $\mathrm{pH}$ of the culture media were measured by oxygen meter (YSI, Model 58) and electric $\mathrm{pH}$ meter (Jenwey Model 3032), respectively. Temperature and light intensity of the culture media were recorded by using a Celsius thermometer and lux meter, respectively. Nitritenitrogen, nitrate-nitrogen and phosphate-phosphorus were determined by Hach kit (DREL/2000) following Clesceri et al. (1989).

\section{Estimation of $S$. platensis cell weight}

The samples were filtered with filter paper (Whatman, $\mathrm{GF} / \mathrm{C}$ ) and shifted to the oven at $105^{\circ} \mathrm{C}$ for 24 hours. The samples were then transferred to the desiccators for cooling and weight was measured using an electric balance. The weight of the dried filter paper was taken.

\section{Before filtering}

\section{Calculation}

Cell weight $(\mathrm{mg} / \mathrm{l})=$ Weight of the filter paper with sample Weight of the filter paper without sample before filtering 


\section{Estimation of chlorophyll a}

Optical densities of the prepared samples were determined at 664, 647 and $630 \mathrm{~nm}$ wave length by using UV spectrophotometer. A blank with $100 \%$ acetone was run simultaneously. Chlorophyll a content was calculated by the following formula (Clesceri et al., 1989):

Chlorophyll $\underline{\mathrm{a}}(\mathrm{mg} / \mathrm{l})=11.85(\mathrm{OD} 664)-1.54(\mathrm{OD} 647)-$ 0.08 (OD 630).

\section{Estimation of specific growth rate (SGR, $\mu /$ day) of microalgae}

The specific growth rate (SGR, $\mu$ /day) of cultured microalgae was calculated by the following equation (Clesceri et al., 1989):

$\operatorname{SGR}(\mu /$ day $)=\ln \left(X_{1}-X_{2}\right) / t_{2}-t_{1}$

Where,

$\mathrm{X}_{1}=$ Biomass concentration at the end of selected time interval,

$\mathrm{X}_{2}=$ Biomass concentration at the beginning of selected time interval, and

$t_{2}-t_{1}=$ Elapsed time between selected time in day.

\section{Analysis of proximate composition}

Proximate composition of algal samples were analyzed in the nutrition laboratory, Faculty of Fisheries, Bangladesh Agricultural University, following standard methods (Horwitz 1984).

\section{Statistical analysis}

Mean and standard deviation were calculated from the experimental data. Then the data were analyzed through oneway analysis of variance (ANOVA) using SPSS followed by Duncan's Multiple Range Test (DMRT) whether any significant difference among the treatment means (Zar 1984).

\section{Results and Discussion}

The highest cell weight $913.13 \mathrm{mg} / \mathrm{l}$ was recorded on the 10th day of culture in the control KM followed by that grown in $0.40,0.30,0.50$ and $0.60 \mathrm{~g} / 1$ of PSPM (Fig. 1). Kosaric medium showed significantly higher $(\mathrm{P}<0.05)$ growth than all other treatments. On the other hand 699.07 $\mathrm{mg} / 1$ S. platensis was recorded in $0.40 \mathrm{~g} / 1 \mathrm{PSPM}$ that was significantly $(\mathrm{P}<0.05)$ higher than that of grown in other concentrations of PSPM. Chlorophyll a content of S. platensis grown in $\mathrm{KM}$ also showed significantly $(\mathrm{P}<0.05)$ higher growth $(8.15 \mathrm{mg} / \mathrm{l})$ than all other treatments. But S. platensis grown in $0.40 \mathrm{~g} / 1 \mathrm{PSPM}$ showed significantly $(\mathrm{P}<0.05)$ higher chlorophyll a content $(6.27 \mathrm{mg} / \mathrm{l})$ than that of grown in other concentrations of PSPM. The chlorophyll a content and optical density were recorded in the range of 3.57 to 8.15 $\mathrm{mg} / \mathrm{l}$ and 1.02 to 2.05 respectively at $620 \mathrm{~nm}$ for all the treatments (Figs. 2 and 3). Miah et al. (2000) got higher cell weight in the control KM then the organic media of sago wastewater. Begum et al. (1998) cultured S. platensis in their developed media. In domestic production of Spirulina they found the yield of $664 \mathrm{mg} / \mathrm{l}$ and $665 \mathrm{mg} / \mathrm{l}$ in their media named Bd-3 and Bd-5 respectively which is more or less similar with present findings. The specific growth rate (SGR, $\mu /$ day) of $S$. platensis on the basis of cell weight and chlorophyll a content was recorded in the ranges of 0.41 to 0.50 and 0.41 to 0.49 , respectively for all the treatments. Toyub et al. (2005) cultured S. platensis in different concentrations $(4.8 \mathrm{~g} / 1,7.2 \mathrm{~g} / 1$ and $9.6 \mathrm{~g} / \mathrm{l})$ of banana leaf ash with added 0.4 $\mathrm{g} / 1$ jack fruit seed powder and $0.2 \mathrm{~g} / 1$ urea. They recorded SGR in the range of $0.41-0.49$ on the basis of chlorophyll a which somehow agreed with the present findings. The SGR on the basis of cell weight and chlorophyll a was recorded significantly $(\mathrm{p}<0.05)$ higher in KM among all the treatments. On the other hand among the four different concentrations of PSPM, $0.40 \mathrm{~g} / 1$ showed significantly $(\mathrm{p}<0.05)$ higher SGR than others. The total biomass on the basis of chlorophyll a content was recorded 238.97 to $546.05 \mathrm{mg} / 1$ among the all treatments (Table II). The total biomass on the basis of chlorophyll a was significantly $(p<0.05)$ higher in $\mathrm{KM}$ than all other treatments. On the other hand $0.40 \mathrm{~g} / 1$ PSPM showed significantly $(\mathrm{p}<0.05)$ higher total biomass than other concentrations (Table II). It might be due to the difference of nutrient released in the media. The highest $\mathrm{pH}$ was observed on the 10th day of culture and the recorded range was 10.04 to 10.56 . The increasing trend of $\mathrm{pH}$ (Fig. 4) up to the stationary phase favoured the growth of $S$. platensis. The decreasing trend of $\mathrm{pH}$ at the death phase might be occurred due to dead cells and other organic loads. The $\mathrm{pH}$ value supported the findings of Richmond (1986), Begum et al. (1998) and Toyub et al. (2005). 
Table II: Mean ( \pm SD) of specific growth rate ( $\mu$ /day) of cell weight, chlorophyll $\underline{a}(\mathrm{chl} . \underline{-a})$ and total biomass $(\mathrm{mg} / \mathrm{l})$ of Spirulina platensis grown in different concentrations of PSPM and KM

\begin{tabular}{l|c|c|c|c|c}
\hline Parameters & $0.30 \mathrm{~g} / 1$ PSPM & $0.40 \mathrm{~g} / 1 \mathrm{PSPM}$ & $0.50 \mathrm{~g} / 1 \mathrm{PSPM}$ & $0.60 \mathrm{~g} / 1 \mathrm{PSPM}$ & $\mathrm{KM}$ \\
\hline SGR of cell wt. & $0.46 \pm 0.00^{\mathrm{c}}$ & $0.48 \pm 0.01^{\mathrm{b}}$ & $0.45 \pm 0.00^{\mathrm{d}}$ & $0.41 \pm 0.01^{\mathrm{e}}$ & $0.50 \pm 0.00^{\mathrm{a}}$ \\
SGR of chl.-a & $0.45 \pm 0.00^{\mathrm{c}}$ & $0.46 \pm 0.01^{\mathrm{b}}$ & $0.43 \pm 0.01^{\mathrm{d}}$ & $0.41 \pm 0.00^{\mathrm{e}}$ & $0.49 \pm 0.00^{\mathrm{a}}$ \\
Total biomass & $370.51 \pm 11.62^{\mathrm{c}}$ & $420.09 \pm 13.45^{\mathrm{b}}$ & $309.99 \pm 10.06^{\mathrm{d}}$ & $238.97 \pm 7.71^{\mathrm{e}}$ & $546.05 \pm 13.75^{\mathrm{a}}$ \\
$($ Chl.-a x 67) & & & & & \\
\hline
\end{tabular}

Different superscripts in each row indicates significant differences $(p<0.05)$

Both the content of $\mathrm{PO}_{4}-\mathrm{P}$ and $\mathrm{NO}_{3}-\mathrm{N}$ of the media were decreasing with the age of the culture up to the stationary phase and then these were increasing again. Use of these nutrients by growing cells in the media may cause the decreasing trend of the amount of $\mathrm{PO}_{4}-\mathrm{P}$ and $\mathrm{NO}_{3}-\mathrm{N}$. At the stationary phase, the content of $\mathrm{PO}_{4}-\mathrm{P}$ and $\mathrm{NO}_{3}-\mathrm{N}$ was recorded in the range of 2.14 to $4.21 \mathrm{mg} / \mathrm{l}$ and 2.47 to 4.38 $\mathrm{mg} / \mathrm{l}$, respectively for all the treatments (Figs. 5 and 6). The content of $\mathrm{NO}_{2}-\mathrm{N}$ and $\mathrm{NH}_{3}-\mathrm{N}$ of the media was the lowest at the beginning and increased with the age of the culture. Decomposition of dead cells of the alga may cause it. These were recorded in the range of 0.10 to $0.23 \mathrm{mg} / \mathrm{l}$ and 0.31 to $0.60 \mathrm{mg} / \mathrm{l}$, respectively among all the treatments on the $10 \mathrm{th}$ day of culture when the growth of $S$. platensis was the highest. Toyub et al. (2005) observed same trend of $\mathrm{PO}_{4}-\mathrm{P}, \mathrm{NO}_{3}-$ $\mathrm{N}, \mathrm{NO}_{2}-\mathrm{N}$ and $\mathrm{NH}_{3}-\mathrm{N}$ contents when they cultured S. platensis in banana leaf ash with added jack fruit seed powder and urea. Islam (2004) also recorded same trend of these parameters when cultured $S$. platensis in press mud and cabbage powder media.

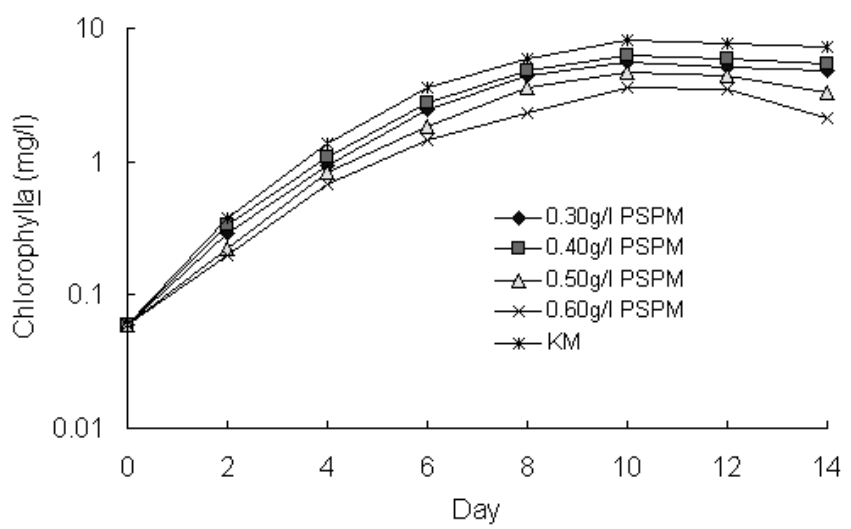

Fig. 1: Semilogarithmic growth curves based on cell weight (mg/l) of Spirulina platensis grown in different concentrations of PSPM and KM

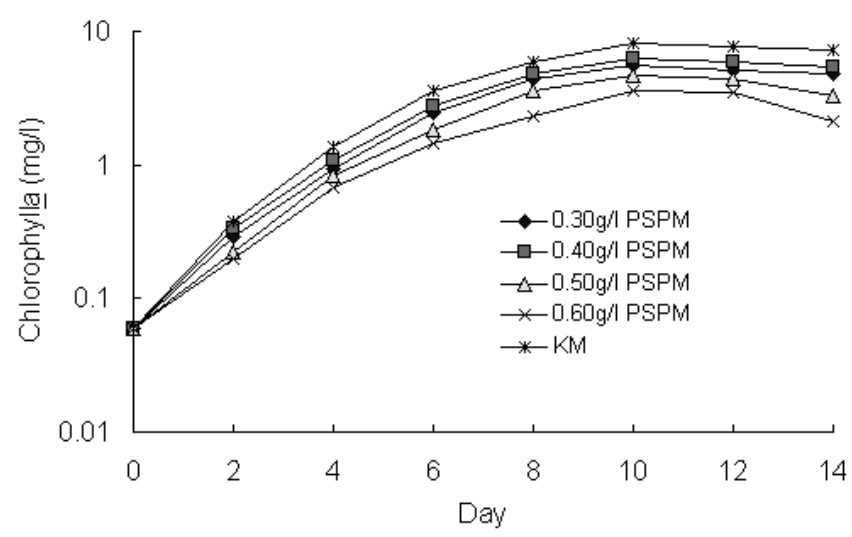

Fig. 2: Semilogarithmic growth curves based on chlorophyll a content (mg/l) of Spirulina platensis grown in different concentrations of PSPM and KM

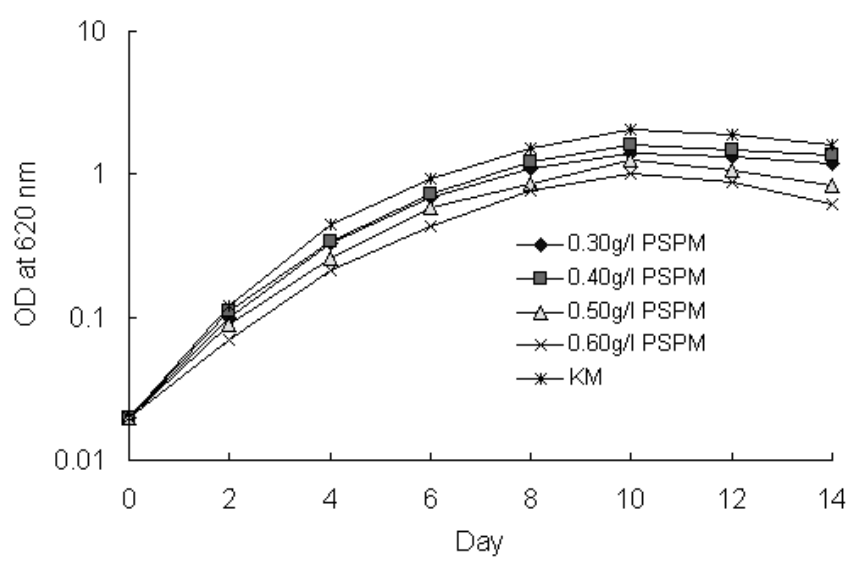

Fig. 3: Semilogarithmic growth curves based on optical density (OD) at $620 \mathrm{~nm}$ of different concentrations of PSPM and KM containing Spirulina platensis 


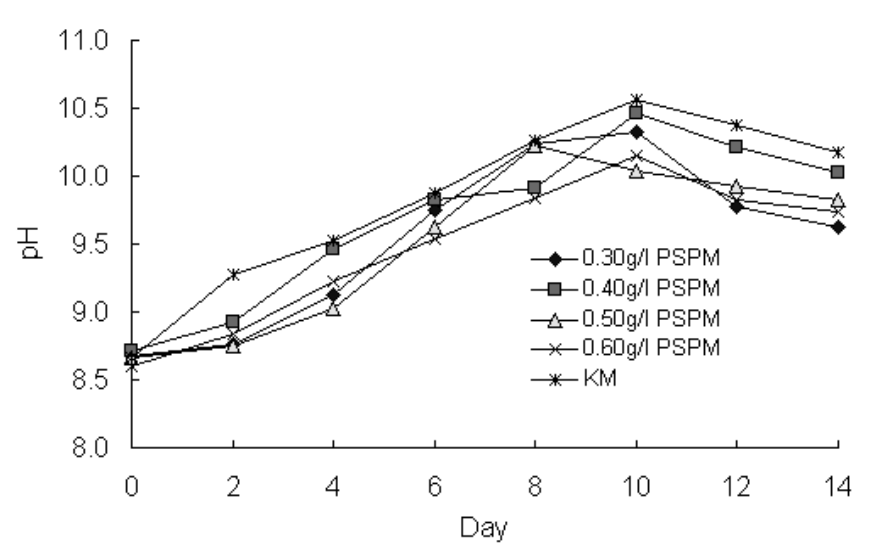

Fig. 4: $\mathrm{pH}$ of different concentrations of PSPM and KM containing Spirulina platensis

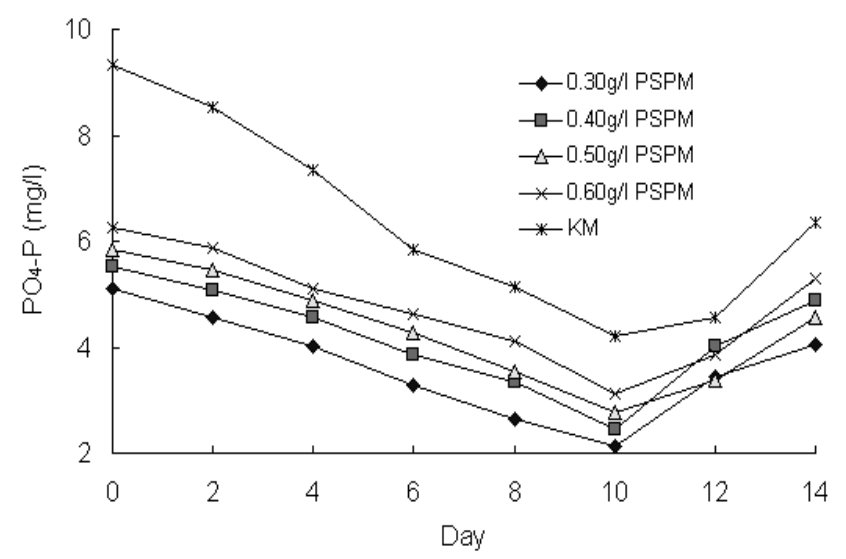

Fig. 5: Phosphate-phosphorus $\left(\mathrm{PO}_{4}-\mathrm{P}\right) \mathrm{mg} / \mathrm{l}$ of different concentrations of PSPM and $K M$ containing Spirulina platensis

At the beginning the range of dissolved oxygen was 3.12 to $3.28 \mathrm{mg} / \mathrm{l}$ but on the 10th day of culture it was recorded in the range of 4.81 to $5.41 \mathrm{mg} / \mathrm{l}$ among all the treatments. The range of average temperature and light intensity was record-

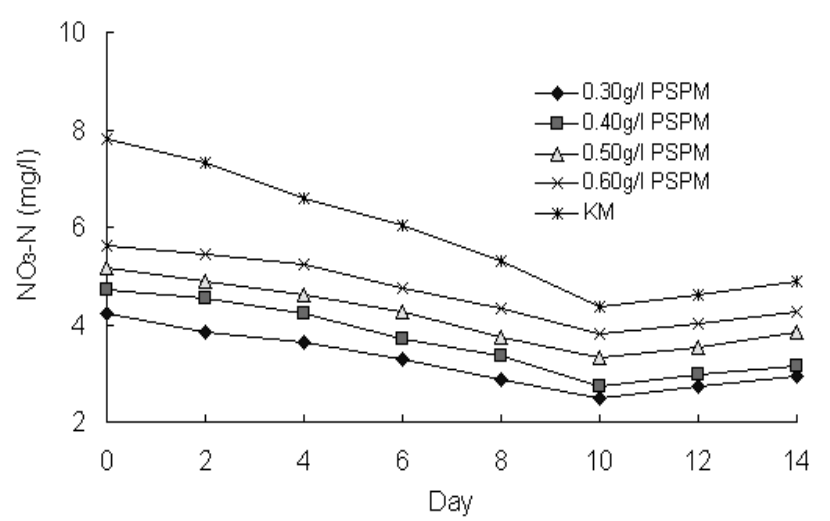

Fig. 6: Nitrate-nitrogen $\left(\mathrm{NO}_{3}-\mathrm{N}\right) \mathrm{mg} / \mathrm{l}$ of different concentrations of PSPM and KM containing Spirulina platensis

ed 28.50 to $30.50^{\circ} \mathrm{C}$ and 2142.51 to $2174.61 \mathrm{lux} / \mathrm{m}^{2} / \mathrm{s}$, respectively during the whole culture period. The range of light intensity, temperature and dissolved oxygen recorded during the study period were found within the favourable ranges for culture of micro algae and supported by Miah et al. (2000), Khan (2003), Islam (2004), Islam et al. (2004) and Toyub et al. (2005).

Proximate compositions of cultured $S$. platensis were studied to know the nutritional values. The highest protein content of S. platensis $58.42 \%$ was recorded when grown in the control KM followed by which grown in $0.40,0.30,0.50$ and 0.60 $\mathrm{g} / \mathrm{l}$ PSPM. The content of lipid was recorded in the range of 10.44 to $12.25 \%$ among all the treatments. The ash and crude fiber content was recorded in the range of 6.46 to $8.51 \%$ and 7.04 to $7.83 \%$, respectively. On the other hand the moisture and nitrogen free extract (NFE) content was recorded in the range of 8.12 to $8.83 \%$ and 5.19 to $15.75 \%$, respectively among all the treatments (Table III). The protein percentage of $S$. platensis grown in KM was significantly $(\mathrm{P}<0.05)$ higher than that of grown in other treatments. Crude lipid, ash,

Table III: Mean values ( \pm SD) of proximate composition (\%) of cultured Spirulina platensis in different concentrations of PSPM and KM

\begin{tabular}{l|c|c|c|c|c}
\hline Composition & $0.30 \mathrm{~g} / 1$ PSPM & $0.40 \mathrm{~g} / 1$ PSPM & $0.50 \mathrm{~g} / 1$ PSPM & $0.60 \mathrm{~g} / 1$ PSPM & KM \\
\hline Protein & $53.67 \pm 0.58^{\mathrm{bc}}$ & $54.87 \pm 1.29^{\mathrm{b}}$ & $52.65 \pm 0.98^{\mathrm{cd}}$ & $51.49 \pm 0.80^{\mathrm{d}}$ & $58.42 \pm 1.07^{\mathrm{a}}$ \\
Crude lipid & $11.52 \pm 0.28^{\mathrm{b}}$ & $12.23 \pm 0.32^{\mathrm{a}}$ & $10.77 \pm 0.54^{\mathrm{c}}$ & $10.44 \pm 0.33^{\mathrm{c}}$ & $12.25 \pm 0.39^{\mathrm{a}}$ \\
Ash & $7.21 \pm 0.31^{\mathrm{b}}$ & $8.19 \pm 0.30^{\mathrm{a}}$ & $7.30 \pm 0.33^{\mathrm{b}}$ & $6.46 \pm 0.37^{\mathrm{c}}$ & $8.51 \pm 0.42^{\mathrm{a}}$ \\
Crude fiber & $7.44 \pm 0.37^{\mathrm{b}}$ & $7.83 \pm 0.26^{\mathrm{a}}$ & $7.15 \pm 0.29^{\mathrm{b}}$ & $7.04 \pm 0.25^{\mathrm{b}}$ & $7.53 \pm 0.30^{\mathrm{ab}}$ \\
Moisture & $8.12 \pm 0.24^{\mathrm{b}}$ & $8.50 \pm 0.23^{\mathrm{ab}}$ & $8.47 \pm 0.27^{\mathrm{ab}}$ & $8.83 \pm 0.26^{\mathrm{a}}$ & $8.13 \pm 0.24^{\mathrm{b}}$ \\
NFE* $^{*}$ & $12.03 \pm 1.57^{\mathrm{b}}$ & $8.41 \pm 0.77^{\mathrm{c}}$ & $13.62 \pm 0.73^{\mathrm{ab}}$ & $15.75 \pm 1.72^{\mathrm{a}}$ & $5.19 \pm 0.67^{\mathrm{d}}$ \\
\hline
\end{tabular}

Different superscripts in each row indicates significant differences $(\mathrm{p}<0.05)$

* Nitrogen free extract. 
moisture and crude fiber percentage of $S$. platensis cultured in $\mathrm{KM}$ and $0.40 \mathrm{~g} / \mathrm{l} \mathrm{PSPM}$ was insignificantly $(\mathrm{P}<0.05)$ different. The NFE content of $S$. platensis grown in different concentration of PSPM was higher $(\mathrm{P}<0.05)$ than that of grown in KM. There is some how similarity of the present study regarding chemical composition of Spirulina with the findings of Olguin (1986); Miah et al. (2000).

So, it is concluded that the growth of S. platensis was maximum in $0.4 \mathrm{~g} / 1$ PSPM than other media of the experiment. Thus, this concentration may be recommended for culture of S. platensis though the control KM gave the highest $(\mathrm{P}<0.05)$ growth.

\section{Acknowledgement}

The authors are indebted to the Director, Bangladesh Agricultural University Research System, Bangladesh Agricultural University, Mymensingh, Bangladesh for providing the fund for successful completion of the research.

\section{References}

Begum S., Noor P., Akhter N. and Majid F. J. (1998). Spirulina culture in Bangladesh VI. Domestic scale production of Spirulina. Bangladesh J. Sc. and Ind. Res., 23(3): 273-278

Clesceri L. S., Greenberg A. E. and Trussell R. R. (1989). Standard Methods for the Examination of Water and Wastewater. American Public Health Association, American Water Works Association and Water Pollution Control Federation; New York. USA, pp 92-1110.

Habib M. A. B. (1998). Culture of selected microalgae in rubber and palm oil effluents and their use in the production of enriched rotifers. Doctoral Thesis, University of Putra. Malaysia, 532pp.

Horwitz W. (1984). Official Methods of the Analysis of the Association of Official Analytical Chemists (14th ed.). Association of Official Analytical Chemists; Washington D. C., USA, 1018 pp.

Islam M. R. (2004). Culture and chemical composition of three important microalgae using different agro-based organic media. PhD Thesis, Department of Aquaculture, Bangladesh Agricultural University, Mymensingh, Bangladesh, 337pp.

Islam M. R., Habib M. A. B., Miah M. I. and Khan A. N. M. A. I. (2004). Growth performance and organic nutrients of Chlorella ellipsoidea grown in cabbage powder media.
J. Asiatic Soc. Bangladesh Sci., 30(1): 71-78.

Khan A. I. A. N. M. (2003). Culture of Live Food Organisms in Sugarcane Industry Waste and their Use as Food for Clarias batrachus Fry. $\mathrm{PhD}$ thesis submitted to the Faculty of Aquaculture, Bangladesh Agricultural University, Mymensingh, Bangladesh, 89pp

Miah M. S., Phang S. M., Chu W. L. and Hashim M. A. (2000). Spirulina culture in digested sago starch factory wastewater. J. Appl. Phycol.,12: 395-400.

Olguin E. J. (1986). Applied biotechnological systems in the aried environment. Appl. Microbiol., 111-134.

Phang S. M. and Chu, W. L. (1999). Algae Culture Collection, Catalogue of Strains. Institute of Postgraduate Studies \& Research, University of Malaya, Kuala Lumpur, Malaysia, 77pp.

Phang, S. M. and Ong, K. C. (1988). Algal biomass production in digested palm oil mill effluent. Biol. Wastes, 25: 177-191.

Richmond A. (1988). Spirulina. In: Borowitzka, M.A. Borowitzka, L. (eds.), Microalgal Biotechnology. Cambridge U. P., Cambridge. UK, pp. 85-121.

Rodhe W. (1978). Algae in culture and nature. Mitteilungen International Vereinigung Limnol., 21: 7-20.

Toyub M. A., Rahman M. M., Miah M. I. and Habib, M. A. B. (2005). Growth performance of Spirulina platensis in three different concentrations of banana leaf ash with added jackfruit seed powder and urea. $J$. Bangladesh Agril. Univ., 3(2): 303-308.

Toyub M.A., Uddin, M. Z., Miah M. I. and Habib M.A.B. 2006. Growth performance of Chlorella ellipsoidea in different concentrations of papaya skin powder media. Bangladesh J. Agric., 31 (1\& 2): 35-43.

Zar J. H. (1984). Biostatistics. prentice-Hall, Inc., Englewood Cliffs, New Jersey, USA, 718pp.

Zarouk C. (1996). Contribution a Letude d une Cyanophycee de Divers Facteurs Physique et Chimiques sur la Croissane et Photosynthese de Spirulina maxima Geitler, Ph.D. Thesis, University of Paris, France, pp. 45-47.

Received: September 27, 2009;

Accepted : January 13, 2011 